\title{
Imparting Teachers' Professional Know-How. Interaction and strategies in supervising teacher students.
}

\author{
Glenn Hultman, Phd, Professor \& Ann-Sofi Wedin, Phd, senior lecturer \\ Department of Behavioural Science and Learning, \\ Linköping University, Sweden
}

This article focuses on the supervision provided during the practical part of teacher education. We are interested in what happens in the interaction between mentors and students [henceforth, we use the word student for teacher student.] and cannot find any clear analyses of this in previous studies (Authors, 2012). A comprehensive international research overview (Clarke, Triggs, \& Nielsen, 2012) also comes to similar conclusions. However, many researchers point out that the research areas of teacher education and teacher learning are often separated (e.g., Oser \& Baeriswyl, 2001; Wideen, Mayer-Smith, \& Moon, 1998). Ahlström and Kallos (1996) focus on Swedish research (see also Hegender, 2010) and note that research has drawn attention to the significance of the practice period but has not analysed communication and what the students learn during their teaching practice. A study conducted by Timperley (2001) within our area of interest focuses on the discussions led by the mentor, within the framework of a training programme in teacher education. There are many studies mentioned but the majority focus on aspects other than learning and knowledge transfer processes. In this article we address the latter.

\section{Teacher education and the school}

Among several earlier summaries of research on teacher education we have found two research overviews that focus on the Swedish (Ahlström and Kallos, 1996; Lindberg, 2003; Erixon Arreman, 2005; Ahlström, 2008, Nilsson, 2008, Hegender, 2010) and the Scandinavian domain (Bergem, Björkqvist, Hansén, Carlgren and Hauge, 1997).

Apart from the research and knowledge overviews mentioned above, we have examined international research, where Cochran-Smith and Fries (2005) provide overviews dating from the 1950s to the present day. They note that several studies stand out as fragmentary and hard to interpret and they note that research on teacher education does not only deal with how the student acquire knowledge and skills.

In a research overview by Grimmet and MacKinnon (1992), specific attention is paid to the professional knowledge of the teacher and its relationship to the teacher education. The authors tone down the idea that teaching ('the discipline of teaching') is an academic subject 
within the teacher education programme, and see it more as an art or skilled craftsmanship. They believe that an assumption is often made that research influences the design of the training programme, that students are taught how to teach, and that this is applied during the practice periods. In this context, attention should be drawn to the fact that there is a 'reformulation problem' (Lindqvist and Nordänger, 2007), meaning that something becomes 'lost in translation' when professional knowledge is compartmentalised. For this reason, focus on the teaching practice and its dynamic can be of significance to the understanding of the mechanisms involved in the process.

Grimmet and MacKinnon (1992) argue for an alternative view, referring to the 'craft knowledge' that the teacher develops in the mystique of their everyday work. The 'craft knowledge' develops from the teacher's own perspective in his or her capacity as 'apprenticein-context' (Author, 2008). In the situation, an informal network of actors around the teacher (pupils, colleagues, principal) is created which provides the foundation for a knowledge base. Hultman uses the term 'contextual knowledge' and especially informal knowledge has priority. The traditional view of 'craft knowledge' is that knowledge is passed on and comes about through 'interaction'. In contrast, Grimmet and MacKinnon (1992) suggest 'situated knowledge' as an alternative to 'craft knowledge'. The discussion of the professional objectives of teachers (Lampert, 2001) focuses on learning processes and comprehension of the didactic triad, i.e., the interaction between teacher - subject/content - pupil. We want to pay attention to the interaction between mentor and student, in line with the idea of 'apprentice-incontext'.

Grimmet and MacKinnon (1992) also present several reflections on teacher education where the student, the mentor and the head of teacher education believe, teach and reflect together, side by side, or 'at one another's elbows'. We learn to teach through creating experiences, sometimes together with others.

In their research overview, Clift and Brady (2005) state that the majority of studies of field courses examined how the new teachers were socialised during the field phase. Furthermore, they also believe that few studies have documented experiences from actual classroom work. They emphasise the need to study in more detail the close context for learning and the social factors that affect the student. In a later analysis, which builds on Clift and Brady (2005), Conklin (2009: 489) notes that data "supports the well-documented view that the field placement and cooperating teachers can play a pivotal role in either reinforcing or contradicting the 
purposes of the teacher education program". We like to focus this study on 'translation', through participation in interaction.

\section{Studies with a focus on the interaction between mentors and students}

In Brusling's (1987) study he makes an analysis of the interaction between mentor and student. In conversations with the students it is evident that they have a positive attitude to the mentor and the teaching practice and that they feel they are learning a great deal. And one of the student (in the school with the most distinct control) does not see the mentor's control as a threat to his/her future independence "...because I'll just brush it off later." (p. 86). The mentor's view is that the student should adopt a teaching style, but still feel independent. Emsheimer and Göhl (1996) give examples of how a controlling style can lead to negative reactions in certain cases, but this can also be seen as a necessity in other situations. In Ahlström and Kallos' (1996) overview we find details of occasional meetings and conversations between mentors and students that generated into heated debates, which can be seen as a sign of the different ways in which lessons can be perceived by the parties that attend them.

Brusling's (1987) analysis and interpretation show that there is a clear orientation towards the ideals of the school where the teaching practice is taking place. This becomes especially clear when a student explains, with hesitation, that the mentor is important, with regard to the value of the lesson analyses provided by the lecturer in teaching methods: “... it is doubtful whether this is of value for one's development as a teacher." (p. 87). In our opinion a strong process is one where dialogue often is characterised by the student developing an idea that is introduced by the mentor.

In one of Franke's (1990) early studies, she analyzes the mentor's and student's perceptions of supervision. Even if Franke has a slightly different way of analyzing and drawing conclusions, the interaction between mentor and student is similar to Brusling and despite the fact that Franke's study was conducted 25 years ago one can detect similarities to what we find today.

Ottesen $(2006,2007)$ analyzes the practical part of Norwegian teacher education with a focus on the conversations (discourse) of the students and mentors during the teaching practice. She is interested in how the interaction constructs the future teacher and the transition between school and university. In the study, no explicit attention is paid to a process perspective and the interaction during the practical part of teacher education. But in one of her articles (Ottesen, 2007), she presents an interesting vignette, which shows how mentors and students interact. One sees how the mentor endeavours to interpret a part of what is happening in a 
positive and constructive way, but also that mentors make some constructive criticism. This is also seen in Hegender's (2010) work, whose vignettes illustrate the interaction between the teacher educator, the mentor and the student, as well as in the work of Nilsson (2008) who shows the interaction between mentor and student.

These studies have more or less another focus and another interest in knowledge, which implies that they do not directly interpret, specifically, the interaction between the mentor and the student in the manner that we do in this article.

The interaction between the student and the mentor implies that learning incorporates corrective elements and alternative interpretations. In other words, adaptation occurs where the teaching practice has a preferential right of interpretation. This can be seen as an example of 'sense-making and surprise'- processes (Louis, 1980).

The interaction between the student and the mentor is created in the situation and becomes significant through that which is done and via their communication. This is a socialisation or an apprentice process (Lave \& Wenger, 1991). It is probably not easy to predict or plan in advance what will happen, as it is affected by many different factors (Nuthall, 2005).

In a discussion of teachers' learning Webster and Wright (2009), argue that we need to focus on how teachers teach, which means an interest in authentic learning and meaning making. According to Tekkumru Kisa and Stein (2015) it is important that teachers learn to "see" teaching in terms of an interaction between task, teacher, and pupils (i.e. instructional triangle) in their study on "teachers' learning to notice". In Craigs' (2009: 1042) terminology, "... the relational world inside classrooms where teachers co-construct meaning in interaction with their students". The importance of the interaction between the teacher and the students is understood as an important aspect in a teacher's professional competence (Lefstein, 2008) because they interact in the "construction" of the teaching act.

In a review of teacher preparation programs, Cochran Smith and Villegas (2016: 3) identifies a number of shortcomings in previous research. They indicate, among other things, that future research:

... would examine - over time - how and under what conditions teacher candidates learn the complex skills of teaching in relation to and as part of their development of a reflective practitioner stance. This would include investigation of the relationships of teacher candidates' beliefs and practice as well as how they learn to negotiate key skills and practices and adapt them to varying needs of students an the context of differing local conditions and cultures of schools. 
Part of that research may involve interaction during teacher training periods. And Horn and Little (2010) shows that teachers' interactions provide opportunities to develop a special sensitivity to the teaching processes "eyes for the classroom" and that school culture helps to reduce the experience that it is the teacher who is always responsible for the problems in practice "relieved one another from blame ... ". This is also something that could be expected and visible in mentors' interactions with students. And Horn and Little recognize that "learning" is largely realized in the teachers' communication and their conversational routines.

In sequences from Author et al (2011), studying the work in the classroom, both positive ('unforeseen incidents may occur') and negative events ('get frustrated because ambition cannot be put into practice') are illustrated. Here the mentor fulfils an important function in that the relationship helps the students to adapt their thinking and evaluation of their efforts; it is not always as negative as one might believe, there are other perceptions (those of the mentor) as shown in the quotation below:

Sometimes it feels that I get side-tracked too often, which means that I think it is difficult to stay focused on the key points that I had intended to deal with during the session. However, my mentor thinks that this is not noticeable but believes that flexibility itself and daring to 'digress' makes the students maintain the pupils' interest and, furthermore, that they get a clearer, holistic picture of what the world looks like. It feels good to hear that. (student, teaching practice log; (Author et al, 2011: 129)

The mentor's interjection gives the student another picture of how one can interpret what is happening. And this is significant. Here the mentor corrects the student's understanding of what is considered to be a meaningful perception, relative to the situation they are in. This can be understood as part of the learning process. This article focuses on the supervision provided during the practical part of teacher education. We are striving to deepen our knowledge on what happens in the interaction between mentors and students during the practicum and how mentors communicate their knowledge to their students.

\section{Method}

We are interested in how one learns to become a teacher and, above all, in how the mentors impart their professional know-how to the students. What strategies, mechanisms and interactions are employed in the process?

\section{Recruiting the mentor}

Our relationship with the mentors (classroom teachers in schools with a supervising assignment) was established earlier, since they participated in the mentor training, which we offered in the context of a two-step research project (Author et al 2011, Authors, 2012a) where the first step involved a mentor training. The aim of this was to release the mentors' experience 
and tacit knowledge (Authors, 2012b). It was ascertained that this training, which had the character of an interaction project rather than a course in the conventional sense, only had a moderate impact on their work during the subsequent practice periods (Authors, 2012a). Our impression was that they worked on as usual, which was also confirmed by the mentors. We cannot exclude the possibility, however, that our presence during the conversations may have influenced the situation, for example, such that the discussions were more profound, although probably not with respect to the form of the discussions themselves; that is, the conversations were typical of the respective mentors relative to the student who was involved in the interaction.

We established collaboration with a number of mentors by means of contacts with representatives from various municipalities and schools and with individuals responsible for the practical part of teacher education in the particular area. This resulted in 11 mentors who showed interest in and participated in our mentor training. There were certain difficulties involved in recruiting teachers generally during this time period, since their workload was felt to be significant and since they did not feel that they could take part in another 'project'. We ended up in a situation where only four of our mentors were assigned students during the autumn term. We thus chose to continue our work with the same mentors during the next period as well, so that altogether we gathered the experiences from six practical parts.

\section{Selecting practice periods and conversations}

Our empirical material is taken from the later teaching practice periods during the teacher education; these periods varied in length between two and six weeks. We thus base our study on 4 mentors, 6 practice periods and 6 students. A total of 27 conversations, each consisting of 30 A4-format pages of transcribed text from conversations lasting between 1 and 1.5 hours. The total text material thus comprises approx. 800 pages.

Participation often took place according to the following sequence: participant observation during one or two lessons before the conversation and, following this, participant observation during the conversation itself, between the mentor and the students. However, occasionally we also took part in the conversation without participating in the lessons. The conversation was recorded and transcribed verbatim, just as it took place, without clarification of the language or the expressions used. The conversations were often carried out in the mentor's classroom but they also occurred in other arenas.

We interacted with the mentors over a longer period of time outside the framework of the classroom. When we examine the transcriptions, we can see that there are both substantial and 
minor differences between them. One of the mentors, for example, is more clearly oriented towards planning, whereas another might be more process-oriented in their conversations. But in all other respects there are similarities with respect to the interaction with students and also as far as strategies for imparting one's know-how are concerned.

\section{The empirical field}

The conversations differed in character depending on the student's experiences and maturity, the school's status and the actual date (situation). The mentors felt that the students we met were on the whole more experienced and mature compared with the students they sometimes found assigned to them. Less experienced students mean that the element of basic knowledge is more strongly pronounced in the mentory discussions.

In the conversations we studied, we also observed such basic features, but to a somewhat lesser extent. A discussion with an external person present means that the parties have someone to relate to even if that person on the whole tries to remain neutral. We were not entirely passive but we were able to interject with comments and questions without disrupting their conversations. The conversations, which we recorded, were surrounded by a number of smaller conversations during each day and week, conversations that took place during lessons and breaks as well as in the mornings and evenings. These 'mini- conversations' were often spontaneous and arose from what was just then taking place. And some of the content from these conversations was repeated in the conversations that were recorded.

\section{The analysis}

In an initial run-through, the entire material of 800 pages was reduced to 150 pages, a roughly edited text where the reading and sorting centred on the imparting and communication of knowledge: strategies, mechanisms and examples. Then there was another reduction of the material in connection with the classification, when the strategies for imparting knowledge were focused on once again and distinguished from sequences where the discussion had to do with the teaching profession and classroom work in general. The categories are situational in nature, that is, they are carried out simultaneously or directly in response to episodes, which took place during the lesson before the discussion (conversation) or during the course of the day. We understand this as "nearness" which is similar to the expression "at the elbows". The material was categorised as indicated below:

- Comments, provides criticism and positive feedback 
- Plan together

- Elucidates and interprets the situation

- Provides research assignments and encourages the carrying out of didactic tests

- Discusses the classroom dynamics

We have tried to capture important strategies and situations, which the mentors employ in order to impart their know-how, both from a formal and an informal perspective. In this way we hope to be able to also identify unconscious attitudes and the tacit dimension.

\section{Findings}

Nearness becomes a kind of collective main category, which means that the mentor uses nearness as a mechanism and strategy in imparting know-how.

\section{Mentor provides comments, criticism and positive feedback}

The mentor often provides constructive criticism in order to highlight the positive aspects of the student's activities in the classroom. In the interaction between the mentor and the student, we could notice a chain of positive feedback and paraphrasing [St (Student): ... I think that there should be another period of peace and quiet - Su (Mentor): ... I would have liked to quiet things down.] The mentor noticed certain critical events and how they were handled or rather how they should have been handled and applied his or her experience at this point.

When one of the mentors employs the blank forms used in student training as a guidance tool, it is also a way to structure reflections together with the student. This becomes a learning opportunity where they discuss and reflect, and the student is given the assignment of writing down his/her own observations, which the mentor then comments on - one can view this as a case where the mentor uses the guidance form for a different purpose. The mentor who used a logbook had developed this method on her own during her many years of working with students.

Frequently, linked sequences with the following content can be observed: the mentor and the student become involved in an interaction with questions, counter-questions and answers. The mentor provides background history and his/her own experiences. The student formulates an idea, testing his/her thoughts. The mentor confirms that this appears reasonable (or rather unsuitable). The student formulates a possible strategy for dealing with the problem and the mentor again provides comments, referring to how one could best reach the individual pupil 
in the classroom. And, as becomes clear from the sequence above, part of the interaction consists of quite practical advice.

Often detailed comments are provided at the same time as the mentor conveys a kind of didactic wisdom. The student is given help with, on the one hand, solving a practical problem, which may arise; on the other hand, he or she is given a sense of classroom dynamics and how one might deal with it. The mentor can impart many different things interwoven in a sequence where there is also a critical dimension. The overriding impression is, however, that a positive mood prevails with a focus on the good aspects. But within this a critical comment may be conveyed which is softened up by a reference to the mentor's own experience, which results in lending even this a more general stamp. The comment then becomes something more than mere criticism. It becomes part of what it means to be a teacher. The mentor may, for example, point out that one must be observant of groups of pupils as well as of the individual pupil.

In certain sequences it becomes especially clear that the mentor acknowledges the insight and the analysis, which the student contributes. They reinforce the student's initiative and explanations. In this case we are dealing with knowledge conveyed by the mentor but where the focus is being placed on the actions performed by the student. This could be understood as a kind of successive moulding, a give-and-take interaction between them where the mentor often focuses on the student's analysis and extends it during the conversation. The structure of the discussion is in reality an interwoven sequence guided by the student's experiences in an actual situation, which occurred before the discussion.

The mentor sometimes uses events in order to expand insights and provide advice. He or she refers to other areas, in which the student has some experience, and extract examples from these areas, '... but you know this since ...'. The counselling is tied to the current situation and becomes an alternative exemplification. The mentor uses his or her own observations concerning what is taking place around the student in the classroom when he or she, for example, takes over responsibility for a lesson.

We also saw how unplanned events could be used in order to bring out interesting observations. In one sequence the student by chance happened to sit on a chair in front near the whiteboard and could thus observe the mentor's work from the teacher's perspective. The interaction between the mentor and the pupils became clearer than if the student had sat at the very back of the classroom. 
The mentor points out, among other things, that a mere look is not enough. What happens in class depends, above all, on the group and what kind of relationship one has established with the pupils. When we participated in the students' lessons we could sometimes quite physically feel 'the relationship', it vibrated and became 'electric', there was a flow. Dispite, such a situation the lesson may feel long, the introduction may feel too long or the instructions may extend past the allotted time so that it appears faulty. The mentors in that case usually point out exactly this, that the lesson was generally too long but that it worked well.

The mentor sometimes uses her experience in order to paint a picture and in this she looks for alternatives to what took place during the lesson. It becomes a kind of thought experiment and a situated discussion. The mentor's experience is conveyed by his or her using the student's earlier experiences, as well as the application of the situation, which has just occurred. The mentor's strategies is close to, "near" the student and the situation or "at the elbows". Towards the end of a sequence we observed, that the mentor employed a seemingly trivial sequence or event to illustrate something of considerably greater importance. It could be a practical tip but also an opportunity to reflect on the classroom dynamics and what one needs to be aware of.

The mentors also use their own experiences in another way, for example by clarifying their thoughts and work patterns. They employ their insights and analyses in order to give advice and introduce detailed comments. They make suggestions and show how they are used to acting and thinking in various situations, ' ... I'll show you a bit more clearly, when I have a lesson at some point, what I mean by that ...' Sometimes the content is factual knowledge, for example, about the class, when the mentor imparts background history and wisdom in situ. Or the mentor talks about the analyses of work done by the class and the dynamics, which arises between the teacher and the class. This can often be a kind of hidden dimension. In some sequences the mentor shows how she listens to the classroom dynamics and how she has succeeded in understanding it and transforming it into a useable insight.

When the supervision points to and makes use of common thoughts, this appears in our material in the transcribed spoken sequences as incomplete sentences - each person bases himself/herself on the other's statements and they follow each other like in a chain. We get the impression that they are speaking the same language. They act and speak as if they already knew what the other person was going to say. They are part of the same dialogue and dis- 
course. Sometimes we could feel that they were speaking at the same time. They show that they understand and view the same thing in largely the same way.

They 'speak the same language' and this can mean that the insight has been imparted? They could have the same insight and assessment even if the student initially expresses a certain kind of objection, which then subsides. At the same time, in such a supervising situation there exists a power relationship where the mentor is clearly the one who has the interpretive priority. In certain sequences we find that they 'see' together ... that is, they have seen the same phenomenon, and we feel we understand that they also perceive things in a similar fashion. Our impression is that the text becomes a web and does not have to be read as separate statements, a fact which is illustrated in our transcriptions. When the pattern is indicated, line by line, a false impression is given of taking turns/hierarchy. The entire time their conversation takes place in an actual situation. They 'see' what they are talking about and the 'language' contains codes and hints.

Our mentors often ask questions during the conversation in order to stimulate and challenge the students. This is a technique, which appears to aim at establishing a focus on something important but also at placing the focus on the student during the conversation, and, given that point of departure, highlighting certain aspects of the lesson in order to provide advice. In certain sequences we could observe a give-and-take situation. The mentor asked questions but he or she also posed guiding and leading questions as a form of help, gave positive feedback on and an interpretation of what the student was thinking, feeling and doing. Recurrent questions are of the following type: '... have you thought about whether you should make some adjustments before the next ... Is there something that you would like to do differently based on that knowledge?' The mentor begins with an assertion before following up with a question. But it can also be the case that the mentor quite simply asks the student to reflect by posing a question.

Both the mentor and the student use their observations in the conversations, observations which can be directed at the lesson itself, at the pupils' learning and other things that are taking place in the classroom dynamics. Both parties observe what is going on around them when they themselves teach but also when others teach. The mentor becomes involved by asking a question following the student's analysis and 'data collection'. The sequences of the entire conversation may be concluded by observations by the student and paraphrasing by the mentor. 


\section{Planning together}

A large part of the student's time during teaching practice is devoted to planning various aspects of the instruction. This means both that the students have their own ideas that are to be realized and that normal instruction has to be carried out. The mentor and the student run through an aspect together, the student performs and they discuss the performance afterwards. They may have planned and discussed before the lesson, but in a subsequent conversation, the mentor confirms and elucidates things ... they talk about it together but the mentor guides or, more precisely, the context guides and influences planning.

Some of the teaching in the planning phases meant that the students could do their own planning which was reminiscent of or the same as that of the mentor, and they learned by 'being cocky', i.e., by imitating ... the student takes part in the conversation and both listens and sees ... It is also the case that the student can be taught in how to 'see'.

A part of professional know-how involves learning how to comprehend different events in different ways as well as different dimensions of classroom dynamics, a subject that we now turn to.

\section{Mentor elucidates and interprets the situation}

Often the mentor has a different opinion than the student, as the mentor sees things in a different way, and this can entail, for example, a more positive interpretation of a given situation. One can view this as an interaction between two people with different backgrounds attempting to comprehend what is taking place. In some sequences we see how the mentor and the student plan and discuss. The student performs and they converse and reflect on the lesson. The mentor corrects, goes into greater depth and adds comments based on his/her own experiences. The mentor makes positive and negative comments but always with positive feedback: he/she reinforces, clarifies, places things in context (the class, for example), expands on the examples, provides new aspects and makes comments.

Sometimes we observed how the mentor offered strong reinforcement and a clear interpretation of the situation, which lends an authoritative bent to the event, when he or she says, 'It is enormously useful for him.' The mentor elucidates and indicates what is the correct interpretation. This is also something that the mentor does in other contexts, for example when the 
student interacts with others at the school. Through comments and interpretations the mentor is able to convey an attitude.

The mentor transmits an attitude. One doesn't have to write, since other things take up so much time - one has it in mind - that is part of the skill. But also by their participation the students are given the opportunity to take part in a community despite the fact that they lack the experience, which the mentor and her colleagues have, 'but precisely that feeling that you realize it but you should also know that that's the way we feel in our profession'. They enter into a common discourse, which shows how a teacher acts, feels and speaks. Even the experienced teacher has feelings and is confronted with conflicting feelings, for example in cases where one wants to be a good leader who is seen as nice while at the same time one nags, gets angry and orders the pupils about. In the conversation between the student and the mentor, the mentor can exert an impact on trying to see other things in the situation.

A subtle influence is exerted when the mentor tries to get the student to 'see things differently'. In the conversation the mentor can bring forth an indirect criticism (as we see it) in the form of a remark, a demand which is formulated to the effect that as a teacher one has to act the way one wants the class to become, which means that one must be interested and show an interest. And here too the conversation is rounded off with a remark, a positive conclusion or rather a transition to the rest of the conversation.

\section{Mentor provides research assignments and encourages testing}

Markedly often we participated in conversations where the mentor asked the student to carry out things which involved trying out an exercise. This could involve encouragement to carry out didactic tests, either combined with the desire that the student should have and cultivate his/her own interests or as a direct urge for them to test something they had just discussed or in connection with something they had seen in the lesson.

In the conversations above it was a matter of actual thoughts and plans about the upcoming lessons. But the mentor also provided other suggestions, things that could be a challenge and sometimes a memory experiment as a basis for further dialogue.

The mentor can initiate mini-experiments aimed at noticing certain things, which one might otherwise ignore, or things, which facilitate the student's self-reflection. This is a more advanced variant of what follows in the next category below. One of our mentors asked one of 
the students to observe the mentor's lesson, as illustrated above, and to focus on what the pupils do that is not related to the lesson in progress. These insights could then be discussed and fulfil a function for both the student and the mentor. In the category that follows similar things can be noticed, but the mentor chooses more directly to emphasize questions involving classroom dynamics.

\section{The mentor discusses classroom dynamics}

The mentor brings up the subject of classroom dynamics as a way to demonstrate the "hidden dimension' in the classroom. It is often a meta-discussion. The student tests the impressions that the mentor uses. The student too can notice things that the mentor is unaware of, for example, things that take place spontaneously, which can be important in the professional discussion. The mentor imparts knowledge about how one can perceive pupils and processes in the classroom, often based on her own experiences. Both can make notes to be used in the discussion. It can be a matter of how one solves a critical situation. Often it is a question of detailed advice, which the mentor links with an actual situation, thus providing a sense of nearness.

In their conversation they can reflect on often seemingly simple situations, which, it turns out, are of great importance in a teacher's work. An example of this kind is how one acts in order to pay attention to and 'see' every pupil, a key issue for any teacher. The student points out that he really has no conscious strategy of how this may be achieved and speaks of intuition, i.e., he has a feeling that this is important, everyday, which the mentor, too, returns to later on in the vignette. In this case both the mentor and the student provide comments in the conversation. The mentor offers examples and illustrations of how this can be accomplished and how one might think. In the discussion two purposes also emerge with respect to the teacher's 'circulating around the classroom', namely, the pupils getting acknowledgement or actually asking for help. Then one might wonder just how much of this very detail the student perceives? Things are different when one has the opportunity to read a transcript in peace and quiet. But we saw in other situations how similar aspects were applied.

A classroom is a very confined space for many pupils and a teacher. An invisible dimension, the thought behind it all - An external observer might think that all classrooms are the same, but almost everything has been thought through in many classrooms, something which is evident from the conversation between the mentor and the student: the placement of the pupils and the location of the desks, the placement of the material, the flow, i.e. designed to 
prevent the formation of queues when the pupils fetch material, the combination of teacher's desk - whiteboard - projector, timetable, planning, and the teacher's movement in the room. Perhaps it is for this reason that the mentor points out that the student moves well around the classroom.

We also heard that the student brought up his impressions in order to test his feelings in front of the mentor, "Something I thought about today ... (St)".

The test often came in the form of a question, which awaited a response rather than formulating the impression directly. Our mentors felt that he/she viewed it as an important part of teacher education that one is allowed to try out and test one's impressions in a secure environment in order to understand classroom dynamics, because the situation can look different if one has one's own class. In addition, there are many different things that students need to be prepared for, i.e. how one 'performs' as a professional [our expression]. The mentor often uses the expression 'to maintain one's calm', or that it is 'the external appearance' that pupils pick up on, and that the teacher is working in a complex system of dynamics.

The mentor is careful to make sure that the student does not place excessive demands on herself and tries to infuse understanding for the profession that awaits her. It is also interesting to note that the mentor stresses the complex aspect of the work and the fact that one must be clear about what one can and cannot achieve. The mentor emphasizes that one can continue to ask colleagues for assistance if things pile up. This is not perceived as a weakness, because everyone remembers the time when they started out as a recently employed teacher.

This type of conversation often focuses on the informal or invisible dimension. It may have something to do with the interaction between the teacher and the pupils when they perceive or misperceive things about one another, when one gains insight into the other's informal strategies, or when the teacher discovers that the pupils too analyse the classroom dynamics and interpret what happens. This becomes part of the dynamics. The mentor and the student may, for example, discuss the dynamics in terms of a chain of events: (1) the teacher plans and carries out his/her strategy; (2) the pupils interpret (potentially in dialogue with the teacher); and (3) the pupils act on the basis of their own interpretations. This type of interaction is often discussed in the conversations we have recorded.

The mentor and the student ascertain that in a classroom a lot of other things happen besides instruction, an on-going, parallel process, a continuous game. This can involve the relationships between girls and boys and between different boys. It often occurs without the 
teacher noticing. Sometimes, however, the gestures are over-explicit, sometimes they are subtle: comments, irritations, shoves. Together the mentor and the student are looking for patterns, at the initiative of the mentor, which also relates to her/his own experiences and informal 'research strategies'. The student is initiated into the inner culture and an important part of professional know-how.

\section{Discussion}

The student learns how to be a teacher and the mentor imparts his/her know-how based on a number of strategies of nearness, or by referring to previous research (Grimmet \& MacKinnon, 1992; Author, 2008), at-the-elbows, i.e., one learns by doing, by proceeding from one's own experience (the student), by applying the mentor's experience and tools (didactic aids and tips), by listening and participating in discussions, by being part of the mentor's explanations and interpretation of events and by being part of what takes place, including feelings and the reactions of others. A summarising expression is that 'one sees one another in action' (cf. Author, 2004; Stedt, 2013). These skills is similar to Hargreaves and Fullan (2012) in terms of human and social capital (relationships) in their discussion of teachers' professional capital.

We believe that this is also a didactic principle, which constitutes a parallel dimension to what occurs in the mentory situation. In the teacher's work in the classroom, the principle of nearness works naturally, since it is the best way to be able to control what is taking place in the classroom. One has to be close to the pupils in order to keep the environment together. If one fails, things can happen that are beyond the control of the teacher, while at the same time the teacher is held responsible. One can, nonetheless, depart from the principle of nearness in a situation where the teacher has established a relationship with a group of pupils such that they guide themselves, for a limited time at least. Thus, 'nearness' once again becomes both a strategy and a didactic principle. In the mentory situation both of them are active. The work of the mentor may be seen as a more or less clear illustration (pedagogy) of an important didactic dimension. You practise what you preach.

In a discussion on the contextual aspect of teacher supervision, Jones and Brown (2011) express the view that principles of complex systems (CAS, Complex Adaptive Systems) can be applied in order to enhance the understanding of the situational dimension of supervision. In our data we see that the mentor is dealing precisely with such a complex environment in his or her pedagogical work. One of the mentors, for example, demonstrates that one can teach improvisation, while others show that one may be trained in how to anticipate those unforeseen events, which continually happen. This means, as Jones and Brown have pointed out, 
that the student is brought into a system and a culture where the mentor attempts to create an understanding of what takes place and why: 'the mentor serves as an exemplar and a guide to a new social world' (p. 412). Another aspect that Jones and Brown identify is what we have indicated by saying that the mentor and the student sometimes 'speak the same language', and we see that by taking turns they come to represent a unit. They think and 'see' in a similar fashion. The authors note that 'We suddenly began to speak as if our relationship was an entity itself ...' (p. 414).

In sequences from Author et al (2011) studying processes in the classroom, both positive things (unforeseen incidents can occur) and negative ones (one gets frustrated because one's ambitions cannot be put into practice) are illustrated. Here the mentor fulfils an important function in that the relationship helps the student to adapt the mentor's thinking and evaluation of the students efforts; it is not always as negative as one might believe, there are other perceptions possible and those can be presented by the mentor. The mentor's interjection gives the student another picture of how one can interpret what is happening. The mentor can 'correct' the student's understanding of what is considered to be a meaningful perception, relative to the situation they are in. This can be understood as part of the learning process.

We thus believe we can see that imparting of know-how takes place by the mentor's working together with the student. Ottesen (2007) shows how mentors and students interact, and this interaction is strongly reminiscent of the data displayed in this study. One sees how the mentor endeavours to interpret a part of what is happening in a positive and constructive way, but also that he or she makes some constructive criticism. They employ what we call 'strategies of nearness'.

Our analysis takes as its point of departure a participatory perspective where we have attempted to illustrate mechanisms of impartment that occur from a local perspective. In our analysis we have not examined the question concerning how the students learn during their practice period in general, but focused on the actions taken by the mentor. The imparting of know-how and the achievement of learning occurs, we believe, in a situation that is created when the mentor works together with the student in the classroom, as seen in its entirety. In this we also include those interactions, which we call planning and reflection. At the heart of the matter is, according to our impression, what occurs in the triad: mentor, student and classroom. This creates a basis for direct and intensive communication, feelings and close observation. Eraut (2010) notes something similar in a study on learning: 
[it's useful to work alongside others] .. To observe and listen ... and to participate. This mode of learning which includes a lot of observation as well as discussion, is extremely important for learning tacit knowledge or the knowledge that underpins routines and intuitive decisions and is difficult to explain. When people see what is being said and done, explanations can be much shorter because the fine detail of incidents, such as the tone of voice or visual features, contributes to their understanding. (p. 47).

We believe that the student learns, as it were, by taking over what occurs and entering into the mentor's work in the overall situation. And that is the reason why mentors employ the strategies they do. Many of the strategies described here are experience-based and emerge in the interaction between the two actors. Other strategies originate in the mentor's experience. And the supervision thus becomes actually something more than simply a number of strategies; it becomes work, which takes place in practice, with both solid instruction and the experience of what it means to be a teacher. Nearness is thus a concept, which serves to illustrate the interaction between mentors and students, and 'nearness' therefor becomes both a strategy and a didactic principle.

\section{Acknowledgement}

This article was supported by a grant from the Swedish Research Council and UVK (Swedish Educational Research Committee) for a study of "Teachers in the practical part of teacher education. A study of professional learning, apprenticeship processes and supervision".

\section{Referenser}

Ahlström, K-G. (2008). Hut! Något fattas.(Something is missing in Higher Education). Pedagogisk forskning i Sverige, Årg. 13, Nr 4, s. 296-301.

Ahlström, K-G. \& Kallós, D. (1996). Svensk forskning om lärararutbildning. Problem och frågeställningar i ett komparativt perspektiv. (A comparative perspective on Swedish Research on Teacher Education). Pedagogisk Forskning i Sverige, 1(2), 65-88.

Brusling, C. (1987). "Efteråt skakar jag bara av mig”. Handledning av praktikantlärare. ("I don't care”. Supervising Teacher Students). (Diss. nr 10). Göteborg: Vasastadens bokbinderi.

Bergem, T., Björkqvist, O., Hansén, S-E., Carlgren, I \& Hauge, T. E. (1997). Research on teachers and teacher education in scandinavia: a retrospective review. Scandinavian Journal of Educational Research, Vol. 41, No. 3-4, pp. 433-458.

Clarke. A., Trigg, V. \& Nielsen, W S. (2012). Cooperationg teachers: A Review of Litterature from 1948-2011. Paper presented at the AERA-conference in Vancouver, Canada, April 13-17, 2012.

Clift, R.T. \& Brady, P. (2005). Research on Methods Courses and Field Experiences. In Cochran Smith, M. \& Zeichner, K.M. (Eds). Studying teacher Education: The Report of the AERA Panel on Research and Teacher Education. Mahwah, NJ: Lawrence Erlbaum Press, pp. 309-336. 
Cochran-Smith, M \& Villegas; A M. (2016). Research on teacher preparation: charting the landscape of a sprawling field. In Gitomer, D. \& Bell, C. Handbook of research on teaching (5th ed.). Washington, DC: AERA (In press).

Cochran Smith, M. \& Fries, K. (2005). Researching Teacher Education Changing Times: Politics and Paradigms. In M. Cochran-Smith and K. Zeichner (Eds.) Studying Teacher Education: The Report of the AERA Panel on Research and Teacher Education. Mahwah, NJ: Lawrence Erlbaum Press, pp. 69-110.

Conklin, H. G. (2009). Purposes, Practices, and Sites: A Comparative case of Two Pathways into Middle School teaching. American Educational Research Journal, Vol. 46, No. 2, pp. 463-500.

Craig, C. J. (2009). The contested classroom space: a decade of lived educational policy in Texas schools. American Educational Research Journal, Vol. 46, No. 4, pp. 1034-1059.

Emsheimer. P. \& Göhl, I. (1996). Handledning i lärarutbildning. (Supervision in Teacher Education). Lund: Studentlitteratur.

Erixon Arreman, I. (2005). Att rubba föreställningar och bryta traditioner. Forskningsutveckling, makt och förändring $i$ svensk lärarutbildning. (Development in Research on Swedish Teacher Education). Diss. Nr 3, Umeå universitet.

Eraut, M. (2010). Knowledge, Working Practice, and Learning. I S. Billett. Learning through Practice. Models, Traditions, Orientations and Approaches. Dordrecht: Springer.

Franke, A. (1990). Handledning i praktiken. En studie av handledares och lärarkandidaters uppfattningar av handledning i lärarutbildningens praktikdel. (Supervision in Teacher Students Practicum). Akad. Avhandl. Linköping: LJ Foto Montage.

Grimmet, P. \& MacKinnon, A. (1992). Craft Knowledge and the Education of Teachers. In Grant, G. Review of Research in Education, Vol. 18, pp. 59-74.

Hargreaves, A. \& Fullan, M. (2012). Professional Capital. Transforming Teaching in Every School. London: Ruthledge.

Hegender, H. (2010). Mellan akademi och profession. En studie om hur lärarkunskap beskrivs och bedöms $i$ verksamhetsförlagd lärarutbildning. (Between Academy and Profession, a Study of Teachers knowledge in Practicum). (Linköping Studies in Pedagogic practices, No. 12) Linköping: Linköpings universitet, Institutionen för beteendevetenskap och lärande.

Horn, I. S. \& Warren Little, J. (2010). Attending to problems of practice: routines and resources for professional learning in teachers' workplace interactions. American Educational Research Journal, Vol. 47, No. 1, pp. 181-217.

Author (2004). Anställda i förändring - Flämtande lågor, ambitioner och vardagsarbete. En longitudinell fallstudie av förändringsprocesser under sex år. (A longitudinal Study of Change Processes during 6 Years). Skapande vetande: Linköping.

Author (2008). Ambiguity as Work. Teachers' Knowledge Creation in Classrooms. NZ Journal of Teachers' Work. Vol. 5, Issue 1, pp. 21-35.

Author et al (2011). Samspelet lärarstuderande-handledare. Den verksamhetsförlagda utbildningen. (The Interplay between Studentteachers and Mentors). I Pedagogisk forskning $i$ Sverige. Årg. 16, nr2, s.118-137. 
Authors (2012) Lärandet och hur det synliggörs under lärarutbildningens praktikperioder. Handledning och överföring av yrkeskunnande. (Supervision and Imparting Teachers Professional Know-how). Didaktisk Tidskrift, Vol 22, Nr 2, s. 335-358.

Jones, R. \& Brown, D. (2011). The mentoring relationship as a complex adaptive system: finding a model for our experience. Mentoring \& Tutoring: Partnership in Learning, Vol. 19, No. 4, November, pp. 401-418.

Lampert, M. (2001). Teaching Problems and the Problems of Teaching. New Haven: Yale University Press.

Lave, J. \& Wenger, E. (1991). Situated learning: legitimate peripheral participation. Cambridge: Cambridge University Press.

Lefstein, A. (2008). Changing classroom practice through the English national literacy strategy: a micro-interactional perspective. American Educational Research Journal, Vol. 45, No. 3, pp. 701-737.

Lindberg, O. (2003). Samtal eller parallella monologer? Svenska avhandlingar om lärarutbildning, perioden 1953-2000. (Swedish Dissertations on Teacher Education, between 1953-2000). Pedagogisk forskning $i$ Sverige, Årg. 8, Nr 3, s. 158-183.

Lindqvist, P. \& Nordänger, U.K.(2007).“Lost in translation?” Om relationen mellan lärares praktiska kunnande och professionella språk. (The relation between Teachers Practical Knowledge and Professional Language). Pedagogisk forskning i Sverige, Årg. 12, Nr 3, s. $177-193$.

Louis, M. (1980). Surprise and sensemaking: What newcombers experience in entering unfamiliar organizational settings. Administrative Science Quarterly, 25, 2, 26-51.

Nilsson, P. (2008): Learning to teach and teaching to learn. Primary science student teachers' complex journey from learners to teachers. (Studies in Science and Technology Education, 19) Linköping: Linköping university.

Nuthall, G. (2005). The cultural myths and realities of classroom teaching and learning? Teachers College Records, 107 (5), 895-934.

Oser, F. K. \& Baeriswyl, F. J. (2001). Choreographies of teaching: Bridging instruction to learning. In Richardson, Research Association (AERA). Review of Education Research, $68(2), 130-178$.

Ottesen, E. (2006). Talk in practice. Analysing student teachers' and mentors' discourse in internship. Dep of teacher education and school development, University of oslo.

Ottesen, E. (2007). Teachers "in the making": Building accounts of teaching. Teaching and teacher education, Vol. 23, Nu. 5, pp. 612-623.

Stedt, L. (2013). Samarbete och lärande. Om friktion, uppgifters komplexitet och erfarenhetsutbyten i samarbete. (Cooperation and Learning in Work Life: Friction, Complexity and everyday work). Doktorsavhandling i pedagogik, nr 17. Stockholms universitet, institutionen för pedagogik och didaktik.

Tekkumru Kisa, M. \& Stein, M. K. (2015). Learning to see teaching in new ways: a foundation for maintaining cognitive demand. American Educational Research Journal, Vol. 52, No. 1, pp. 105-136.

Timperley, H. (2001). Mentoring conversations designed to promote student teaching learning. Asia-Pacific Journal of Teacher Education, 29 (2), pp. 111-123. 
Webster, A. \& Wright, A. (2009). Reframing professional development through understanding authentic professional learning. Review of Educational Research, Vol. 79, No. 2, pp. 702-739.

Authors (2012). Influens och konsistens. Om vad som påverkar handledningen under den verksamhetsförlagda perioden inom lärarutbildningen. (Factors influencing Supervision during Practicum in Teacher Education). Pedagogisk forskning I Sverige, Årg 17, Nr 1-2, s 81-98.

Wideen, M. F., Mayer-Smith, J., \& Moon B. (1998). A critical analysis of the research on learning-to-teach. Review of Education Research, 68 (2), 130-178. 